\title{
Efficiency phosphorescent OLEDs with a low roll-off based on a hetero-triplet iridium complex
}

\author{
Liangliang Han a, Dongyu Zhang b, *, Jun Wang a , Zhenggang Lan a , Renqiang Yang a, * \\ ${ }^{a}$ CAS Key Laboratory of Bio-based Materials, Qingdao Institute of Bioenergy and Bioprocess Technology, Chinese Academy of Sciences, Qingdao 266101, \\ China \\ b Suzhou Institute of Nano-Tech and Nano-Bionics, Chinese Academy of Sciences, Suzhou 215123, China
}

\section{A R T I C L E I N F O}

\section{Article history:}

Received 4 June 2014

Received in revised form

29 September 2014

Accepted 2 October 2014

Available online 12 October 2014

\section{Keywords:}

Heterocyclometalated iridium complex

Hetero-triplet iridium complex

Triplet-triplet annihilation

Efficiency roll-off

Exciton density

OLED

\begin{abstract}
A B S T R A C T
In order to explore the triplet-triplet annihilation in cyclometalated iridium complexes, a hetero-triplet iridium complex [ $\operatorname{Ir}(\mathrm{ppy})_{2} \mathrm{pbi}$ ] employing two 2-phenylpyridine (Hppy) ligands and one 1,2-diphenyl-1Hbenzo[d]-imidazole (Hpbi) ligand with similar triplet energies was synthesized. A device based on $\operatorname{Ir}(\text { ppy })_{2}$ pbi exhibited high current efficiency $26.7 \mathrm{~cd} / \mathrm{A}$ at high doping concentration $12 \mathrm{wt} \%$. More interestingly, the current efficiency was still maintained at $25.8 \mathrm{~cd} / \mathrm{A}$ when the current density was above $253.2 \mathrm{~mA} / \mathrm{cm}^{2}$. The efficiency roll-off was only about 3.4\%, much lower than that of traditional cyclometalated iridium complexes. It is proposed that the complicated energy level and unsymmetical ligand in $\operatorname{Ir}(\mathrm{ppy})_{2}$ pbi may help to suppress the triplet-triplet annihilation.
\end{abstract}

๑) 2014 Elsevier Ltd. All rights reserved.

\section{Introduction}

Organic light-emitting devices (OLEDs) are currently an active research area due to their potential applications in flat-panel displays and solid state lighting [1-5]. Octahedral $4 \mathrm{~d}^{6}$ and $5 \mathrm{~d}^{6}$ metal complexes based phosphorescent materials, especially the iridium complexes, have attracted much attention for improving OLED efficiency because the close-lying $\pi-\pi^{*}$ and metal to ligand charge transfer (MLCT) states in these complexes together with the heavy atom effect enhance the spin-orbit coupling, which results in utilization of both singlet and triplet excitons, causing nearly unity of internal quantum efficiency [5-9]. However, triplet-triplet annihilation (TTA) exists in phosphorescent OLEDs because of the long lifetime of triplet exciton and high triplet exciton concentration in the emitting layer [10-13]. Tris(2phenylpyridine)iridium $\left[\operatorname{Ir}(\mathrm{ppy})_{3}\right]$, one of the most studied phosphorescent dyes frequently shows efficiency roll-off when used in phosphorescent OLEDs [14-16]. Though the TTA can be suppressed to a certain extent by optimized device structure, the triplet lifetime $1.6 \mu \mathrm{s}$ of $\operatorname{Ir}(\mathrm{ppy})_{3}$ may be too long to avoid the TTA. Therefore, developing short lifetime triplet exciton phosphorescent materials will be an effective strategy to suppress the TTA. Shu et al. [17] developed a cyclometalated osmium complex with short triplet lifetime $96 \mathrm{~ns}$,

\footnotetext{
* Corresponding authors.

E-mail addresses: dyzhang2010@sinano.ac.cn (D. Zhang), yangrq@qibebt.ac.cn (R. Yang).
}

which exhibited a less-pronounced efficiency roll-off at high current densities. We also developed a novel phosphor with triplet lifetime of $3.92 \mathrm{~ns}$, and the efficiency roll-off was only $28.2 \%$ at $100 \mathrm{~mA} / \mathrm{cm}^{2}$ with low doping concentration $2 \mathrm{wt} \%$ [18]. Although developing short lifetime phosphors can effectively suppress the TTA, however, materials can only be designed by serendipity. Taking into account the chemical structure of cyclometalated iridium complexes, three homocyclometalated ligands are always employed like $\operatorname{Ir}(\mathrm{ppy})_{3}$ and tris[1phenylisoquinoline]iridium $\left[\operatorname{Ir}(\mathrm{piq})_{3}\right]$, commercialized materials for green and red phosphorescent OLEDs. Lee [19] has reported a novel red phosphorescent iridium complex $\operatorname{Ir}(\mathrm{ppy})_{2}$ piq by intramolecular energy transfer from the MLCT of Ir-ppy to Ir-piq to improve the efficiency by $20 \%$, however, there was no improvement of the TTA. Thus, here we design a new hetero-triplet iridium complex Ir(ppy) ${ }_{2}$ pbi employing ppy and pbi with similar triplet energy. Because of the different triplet energies existed in $\operatorname{Ir}(\mathrm{ppy})_{2} \mathrm{pbi}$, we thought the TTA in the emitting layer will be different from homo-triplet exciton complexes.

The emitting mechanisms of $\operatorname{Ir}(\mathrm{ppy})_{3}, \operatorname{Ir}(\mathrm{ppy})_{2} \mathrm{piq}$ and $\operatorname{Ir}(\mathrm{ppy})_{2}$ pbi were shown in Fig. 1. For $\operatorname{Ir}(\mathrm{ppy})_{3}$, the green phosphorescence emitted from the decay of degenerate ${ }^{3} \mathrm{MLCT}$ energy level between iridium atom and ppy ligand, TTA became more serious as the triplet exciton density increased. For $\operatorname{Ir}(\mathrm{ppy})_{2}$ piq, there was still no improvement about the TTA because of high exciton concentration of Ir-piq caused by the intramolecular energy transfer from Ir-ppy to Ir-piq which resulted in a pure red 

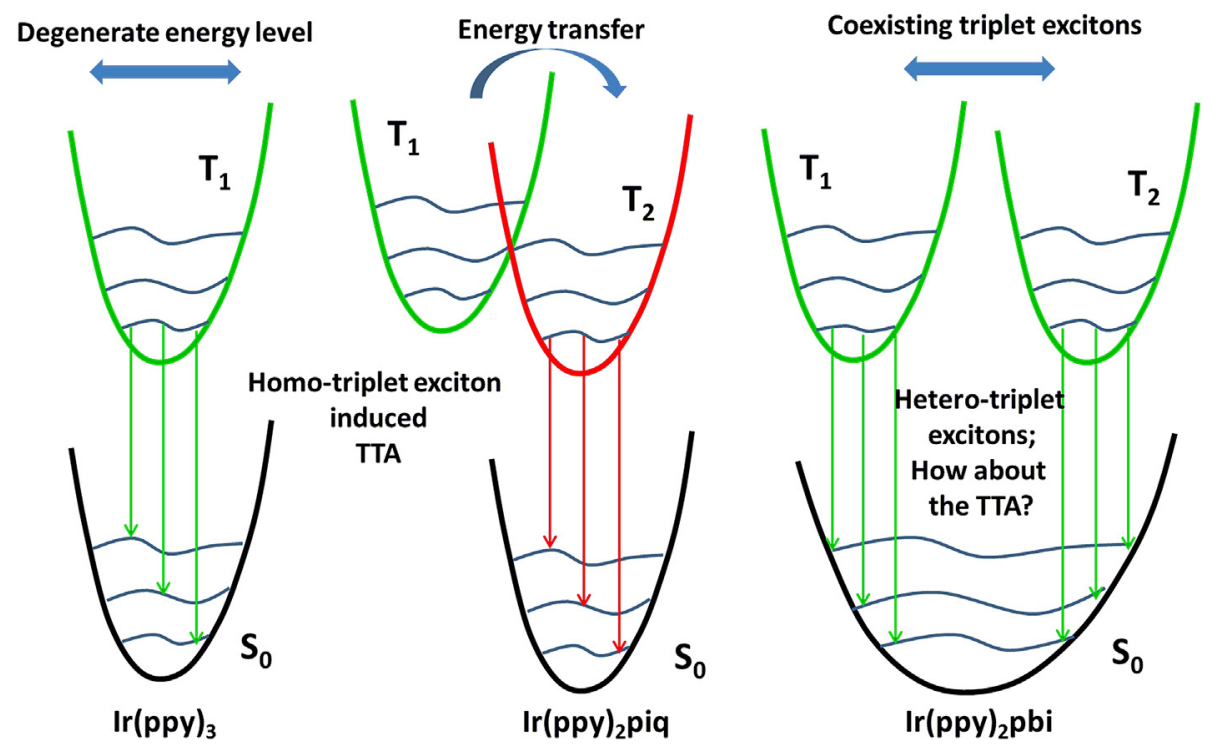

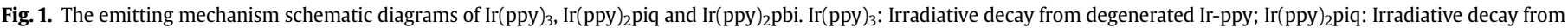
Ir-piq because of the intramolecular energy transfer; $\operatorname{Ir}(\mathrm{ppy})_{2}$ pbi: Irradiative decay from both Ir-ppy and Ir-pbi.

phosphorescence. For Ir(ppy $)_{2}$ pbi, the triplet energy levels of Irppy and Ir-pbi were similar, both Ir-ppy and Ir-pbi contribute to the phosphorescence without intramolecular energy transfer. Experiments show that $\operatorname{Ir}(\mathrm{ppy})_{2}$ pbi exhibits low photoluminescence quantum yield of 0.21 which may be caused by the low triplet density in the emitting layer. Theoretical calculations show that the highest occupied molecular orbital (HOMO) and the lowest unoccupied molecular orbital (LUMO) energy levels of $\operatorname{Ir}(\mathrm{ppy})_{2}$ pbi were more complicated than that of $\operatorname{Ir}(\mathrm{ppy})_{3}$ because the introduction of different cyclometalated ligands destroys the high symmetry of cyclometalated complex. It supposed that the complicated energy level and unsymmetical ligand play an important role in suppression TTA. As a result, efficient green phosphorescent OLEDs are obtained with efficiency roll-off of 3.4\% at high doping concentration $12 \mathrm{wt} \%$.

\section{Experimental}

\subsection{Reagents and measurements}

Hppy was purchased from Aldrich, all reactions were performed under argon. Solvents were carefully dried and distilled from appropriate drying agents prior to use. Commercially available reagents were used without further purification unless otherwise stated. All reactions were monitored by using thin-layer chromatography (TLC) with Merck precoated glass plates. Compounds were visualized with UV-light irradiation at 254 and $365 \mathrm{~nm}$. High resolution mass spectra (HRMS) were obtained using a Bruker Maxis UHR-TOF, Ion Source: APCI system. Nuclear magnetic resonance (NMR) spectra were measured in appropriate deuterated solvents $\left(\mathrm{CDCl}_{3}\right.$ or DMSO- $\left.d_{6}\right)$ on a Bruker AVANCE $600 \mathrm{MHz}$ Fourier transform NMR spectrometer; chemical shifts were quoted relative to the internal standard tetramethylsilane for ${ }^{1} \mathrm{HNMR}$ data. Absorption and photoluminescence spectra were measured with a Hitachi U-4100 UV-Vis-NIR scanning spectrophotometer and HORIBA JOBIN YVON FluoroMax-4 spectrophotometer, respectively. The electrochemistry characteristics of the two complexes were investigated using a cyclic voltammetry employing a glass carbon electrode as working electrode, a platinum wire as counter electrode and an $\mathrm{Ag} / \mathrm{AgCl}(3.0 \mathrm{M} \mathrm{KCl})$ electrode as reference electrode. The cyclic voltammograms were obtained from a one- compartment glass cell in dichloromethane containing $10^{-3} \mathrm{M}$ iridium complexes and $0.1 \mathrm{M}$ tetra( $n$-butyl)ammonium hexafluorophosphate $\left(n-\mathrm{Bu}_{4} \mathrm{NPF}_{6}\right)$ as a supporting electrolyte, where the scan rate was $100 \mathrm{mV} / \mathrm{s}$, the HOMO and LUMO energy level was calculated as the reference method [20].

\subsection{Device fabrication and measurements}

OLEDs were prepared on a glass substrate pre-coated with a 130-nm-thick indium-tin-oxide (ITO) layer with a sheet resistance of $\sim 20 \Omega /$ sq. Prior to organic layer deposition, the substrate was degreased with solvents and cleaned for $5 \mathrm{~min}$ by exposure to a UV-ozone ambient, then it was immediately loaded into the evaporation system. With a base pressure of $\sim 3 \times 10^{-4} \mathrm{~Pa}$, the organic and metal cathode layers were grown successively by using an in vacuo mask exchange mechanism without breaking the vacuum. Firstly, a 10 -nm-thick 4,4',4" -tris $(N$-3-methylphenyl- $N$-phenylamino)triphenylamine (m-MTDATA) hole injection layer (HIL) was deposited, followed by a 20 -nm-thick 4, 4'-bis[N-(1-naphthyl)$\mathrm{N}$-phenylamino]biphenyl (NPB) hole transporting layer (HTL). Then a 30-nm-thick light-emitting layer (EML) consisting of various weight ratio iridium complexes doped into a 4,4'-bis(9H-carbazol9-yl)biphenyl (CBP) host was prepared via thermal codeposition. Next, a 30-nm-thick 1,3,5-tri(1-phenyl-1H-benzo[d]imidazol-2-yl) phenyl (TPBi) layer was used to block hole and transport electron. A shadow mask with rectangular $2 \mathrm{~mm} \times 2 \mathrm{~mm}$ openings was used to define the cathode consisting of a 1-nm-thick LiF layer, followed by a $100-n m$-thick Al layer. The electroluminescence spectra were recorded with a PR655 spectrophotometer. The brightness-currentvoltage $(B-I-V)$ characteristics of OLEDs were measured with Keithley 2400. All the measurements were carried out at room temperature under ambient conditions.

\subsection{Theoretical calculations}

The molecular structures and corresponding molecular orbital were obtained at the B3LYP [21,22]/def2-SVP [23] level. All the calculations were performed using ORCA [24] program. 


\subsection{The general procedure for the synthesis of $\operatorname{Ir}(p p y){ }_{2} p b i$}

Bis[1,2-diphenyl-1H-benzo[d]-imidazole](2-phenylpyridine)iridiu$m(I I I)$ [Ir(ppy) $\left.)_{2} \mathbf{p b i}\right]$ : Hppy $(0.31 \mathrm{~g}, 2.0 \mathrm{mmol})$ was dissolved into a mixed solution of 2-ethoxyethanol $(12 \mathrm{~mL})$ and water $(4 \mathrm{~mL})$ in a $25 \mathrm{~mL}$ round bottomed flask, and then $\mathrm{IrCl}_{3} \cdot 3 \mathrm{H}_{2} \mathrm{O}(0.28 \mathrm{~g}, 0.8 \mathrm{mmol})$ was added. The mixture was stirred under nitrogen at $120^{\circ} \mathrm{C}$ for $12 \mathrm{~h}$. The mixture was cooled to room temperature and the precipitate was collected and washed with water, ethanol, and acetone, then dried in vacuum to give a cyclometalated $\mathrm{Ir}-\mu$-chloro-bridged dimer. The dimer complex, Hpbi (0.27 g, $1.0 \mathrm{mmol}), \mathrm{Na}_{2} \mathrm{CO}_{3}(0.34 \mathrm{~g}, 3.2 \mathrm{mmol})$ and $5 \mathrm{~mL}$ glycerol were charged into a round bottomed flask, the mixture was then heated to $240{ }^{\circ} \mathrm{C}$ under an argon atmosphere for another $12 \mathrm{~h}$. After cooling to room temperature, the mixture was poured into $100 \mathrm{~mL}$ water, yellow precipitate was filtered off and washed with water, ethanol and ether. The crude product was purified by silica column chromatography with dichloromethane/petroleum ether $(1: 2, \mathrm{v} / \mathrm{v})$ as the eluent to give $0.29 \mathrm{~g} \mathbf{I r}(\mathbf{p p y})_{2} \mathbf{p b i}$ as a yellow powder. Yield: $47.5 \%, 0.14 \mathrm{~g}$. $\operatorname{Ir}(\mathbf{p p y})_{3}$ can also be obtained as a byproduct, yield: $27.5 \% .{ }^{1} \mathrm{HNMR}\left(\mathrm{CDCl}_{3}, 600 \mathrm{MHz}\right): 7.90(\mathrm{t}, J=6.4 \mathrm{~Hz}$, $2 \mathrm{H}), 7.85(\mathrm{~d}, J=4.8 \mathrm{~Hz}, 1 \mathrm{H}), 7.77(\mathrm{~d}, J=5.4 \mathrm{~Hz}, 1 \mathrm{H}), 7.69-7.59(\mathrm{~m}, 7 \mathrm{H})$, $7.50-7.47(\mathrm{~m}, 2 \mathrm{H}), 7.06$ (t, $J=7.8 \mathrm{~Hz}, 1 \mathrm{H}), 6.97(\mathrm{~d}, J=7.8 \mathrm{~Hz}, 1 \mathrm{H})$, $6.92-6.78(\mathrm{~m}, 10 \mathrm{H}), 6.72(\mathrm{t}, J=7.8 \mathrm{~Hz}, 1 \mathrm{H}), 6.63(\mathrm{~d}, J=7.8 \mathrm{~Hz}, 1 \mathrm{H}), 6.53$ $(\mathrm{t}, J=7.8 \mathrm{~Hz}, 1 \mathrm{H}), 6.05(\mathrm{~d}, J=8.4 \mathrm{~Hz}, 1 \mathrm{H}) ;{ }^{13} \mathrm{CNMR}\left(\mathrm{CDCl}_{3}, 150 \mathrm{MHz}\right)$ : 167.65, 166.68, 163.39, 162.61, 161.33, 148.06, 144.33, 143.92, 140.86, $137.90,137.85,136.91,136.87,136.32,135.90,135.80,134.10,130.38$, $130.13,129.89,129.78,129.74,128.53,128.17,125.25,123.94,123.72$, 123.23, 122.38, 122.00, 121.29, 119.66, 119.52, 119.09, 118.66, 118.54, 115.23, 110.53; HRMS (APCI): $m / z$ calcd for $\mathrm{C}_{41} \mathrm{H}_{29} \mathrm{IrN}_{4}: 770.2021$; found: $771.2094(\mathrm{M}+\mathrm{H})^{+}$.

\section{Results and discussion}

\subsection{Synthesis}

The cyclometalated ligand Hpbi was synthesized by condensation of $\mathrm{N}$-phenyl-o-phenylenediamine and benzaldehyde in 2-ethoxyethanol as described in literature [25], after purified by column chromatography using petroleum ether and ethyl acetic as eluent, off white powder was obtained in $72 \%$ yield. The synthesis of $\operatorname{Ir}(\mathrm{ppy})_{2} \mathrm{pbi}$ was carried out according to the reference method $[26,27]$ as shown in Scheme 1 . Hppy was used to react with $\mathrm{IrCl}_{3} \cdot 3 \mathrm{H}_{2} \mathrm{O}$ to give cyclometalated $\mathrm{Ir}-\mu$-chloro-bridged dimer, which could react with Hpbi to afford heterocyclometalated $\operatorname{Ir}(\mathrm{p}$ py $)_{2} \mathrm{pbi}$, in the presence of $\mathrm{Na}_{2} \mathrm{CO}_{3}$. More interestingly, $\operatorname{Ir}(\mathrm{ppy})_{3}$ can also be obtained as a byproduct when we attempted to purify $\operatorname{Ir}(\mathrm{ppy})_{2}$ pbi on a silica gel column with dichloromethane and hexane as eluent, which was used for device fabrication directly. Both the complexes show strong phosphorescence on silica gel plates under the excitation of $365 \mathrm{~nm}$.

\subsection{Photophysics characteristics}

The UV-vis absorption and photoluminescence spectra of complexes $\operatorname{Ir}(\mathrm{ppy})_{3}$ and $\operatorname{Ir}(\mathrm{ppy})_{2}$ pbi in dichloromethane solutions were shown in Fig. 2. Both the complexes show similar absorption between 375 and $525 \mathrm{~nm}$, however, a difference was obvious in the region 325-375 $\mathrm{nm}$ because of the introduction of the pbi ligand, from which we can conclude both the MLCT of ppy and pbi were excited according to literature [19]. $\operatorname{Ir}(\mathrm{ppy})_{3}$ and $\operatorname{Ir}(\mathrm{p}-$ py) $)_{2}$ pbi show strong green phosphorescence with a peak maximum wavelength at 514 and $517 \mathrm{~nm}$ with photoluminescence quantum yield $(\varphi)$ of 0.40 and 0.21 , respectively, calculated based on our previous report [28]. In the heterocyclometalated complex $\operatorname{Ir}(\mathrm{ppy})_{2} \mathrm{pbi}$, the triplet MLCT state of Ir-ppy and Ir-pbi were 2.41 and $2.37 \mathrm{eV}$, respectively, estimated from the emission of $\operatorname{Ir}(\mathrm{ppy})_{3}$ [14] and tris(1,2-diphenyl- $1 H$ benzimidazol)iridium [ $\operatorname{Ir}(\mathrm{pbi})_{3}$ ] [29]. Therefore the $0.04 \mathrm{eV}$ difference between the triplet MLCT state of Ir-ppy and Ir-pbi was too small for the occurrence of efficient intramolecular energy transfer [30]. That is, the $\Delta G$ between the MLCT of acceptor and donor was $<<0 \mathrm{eV}$, so inefficient energy transfer should be existed in $\operatorname{Ir}(\mathrm{ppy})_{2}$ pbi molecule. As shown in Fig. 1, both the triplet of Ir-ppy and Ir-pbi contribute to the phosphorescence.

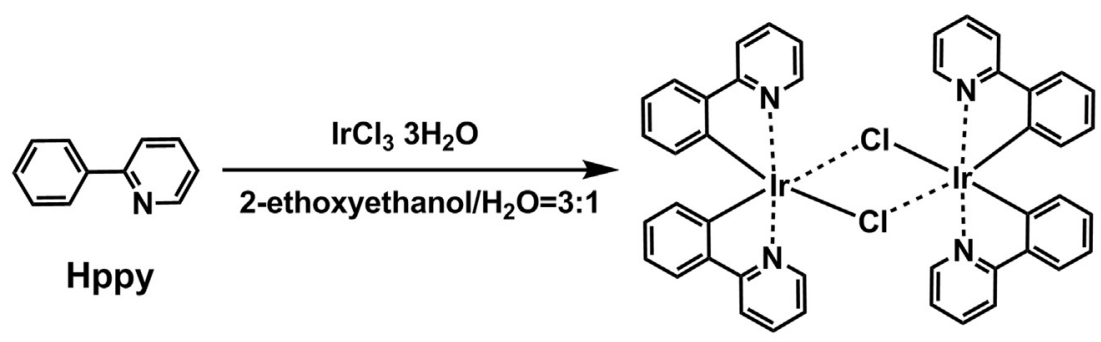

Dimer

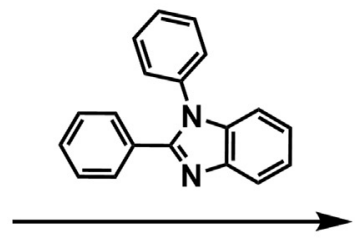

Glycerol, $240^{\circ} \mathrm{C}$

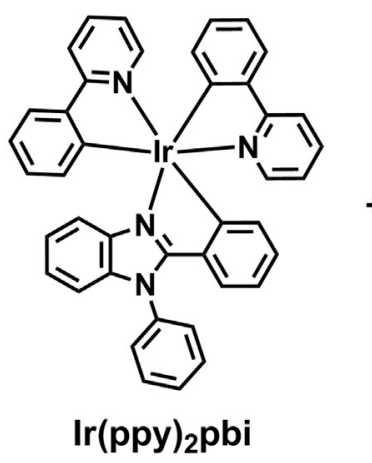

Scheme 1. Synthetic route of $\operatorname{Ir}(\mathrm{ppy})_{2} \mathrm{pbi}$.

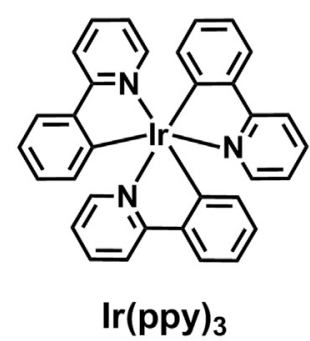

$\operatorname{Ir}(\text { ppy })_{3}$

. Synthetic route of ir(ppy) 2 pbi. 


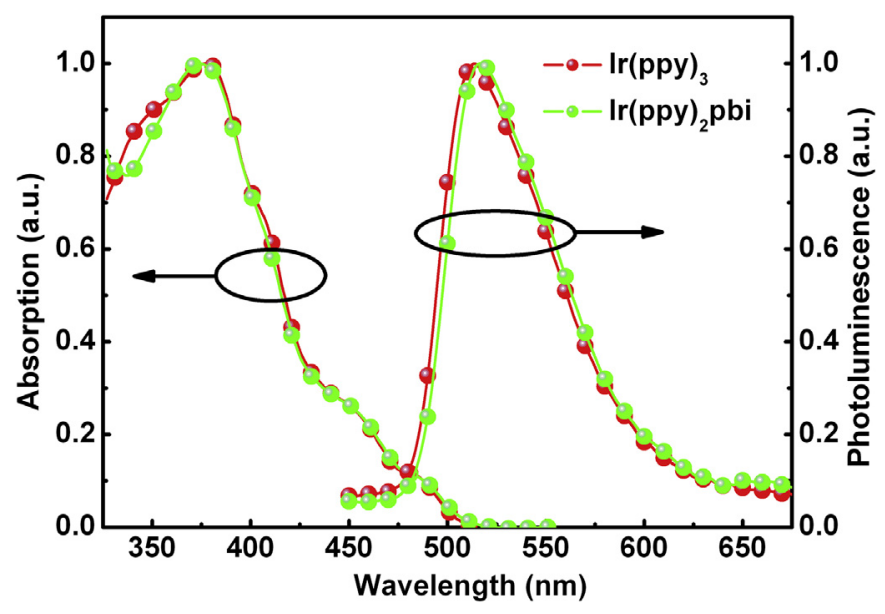

Fig. 2. UV-vis absorption and photoluminescence spectra of $\operatorname{Ir}(\mathrm{ppy})_{3}$ and $\operatorname{Ir}(\mathrm{ppy})_{2} \mathrm{pbi}$ in dichloromethane solution (excited at $300 \mathrm{~nm}$ ) at room temperature.

\subsection{Electrochemistry characteristics}

Fig. 3 depicts the cyclic voltammograms of both the complexes. The onset oxidation $\left(E_{\mathrm{ox}}\right)$ of $\operatorname{Ir}(\mathrm{ppy})_{3}$ and $\operatorname{Ir}(\mathrm{ppy})_{2} \mathrm{pbi}$ were 0.64 and $0.61 \mathrm{~V}$, respectively, which were usually considered as the metal-centered couple. i. e. IrIII/IrIV of the complexes [31,32]. The oxidation and reduction onset of ferrocence were 0.78 and $0.26 \mathrm{~V}$, respectively, then the HOMO of $\operatorname{Ir}(\mathrm{ppy})_{3}$ and $\operatorname{Ir}(\mathrm{ppy})_{2}$ pbi were estimated to be -4.92 and $-4.89 \mathrm{eV}$, respectively, according to the previously reported method [33]. The optical band gaps $\left(E_{g}\right)$ of $\operatorname{Ir}(\mathrm{ppy})_{3}$ and $\operatorname{Ir}(\mathrm{ppy})_{2}$ pbi were calculated about 2.08 and $2.07 \mathrm{eV}$, respectively, according to the absorption edge $\left(\lambda_{\text {edge }}\right)$ in their dichloromethane solutions (Fig. 2). As a result the LUMO were calculated from HOMO and $E_{g}$, estimated to be -2.84 and $-2.82 \mathrm{eV}$, respectively. By replacing ppy with pbi, the HOMO and LUMO changed slightly because of the similar electron deficient ability of benzoimidazole compared to pyridine. The photophysics and electrochemistry characteristics of complexes $\operatorname{Ir}(\mathrm{ppy})_{3}$ and $\operatorname{Ir}(\mathrm{ppy})_{2}$ pbi were summarized in Table 1.

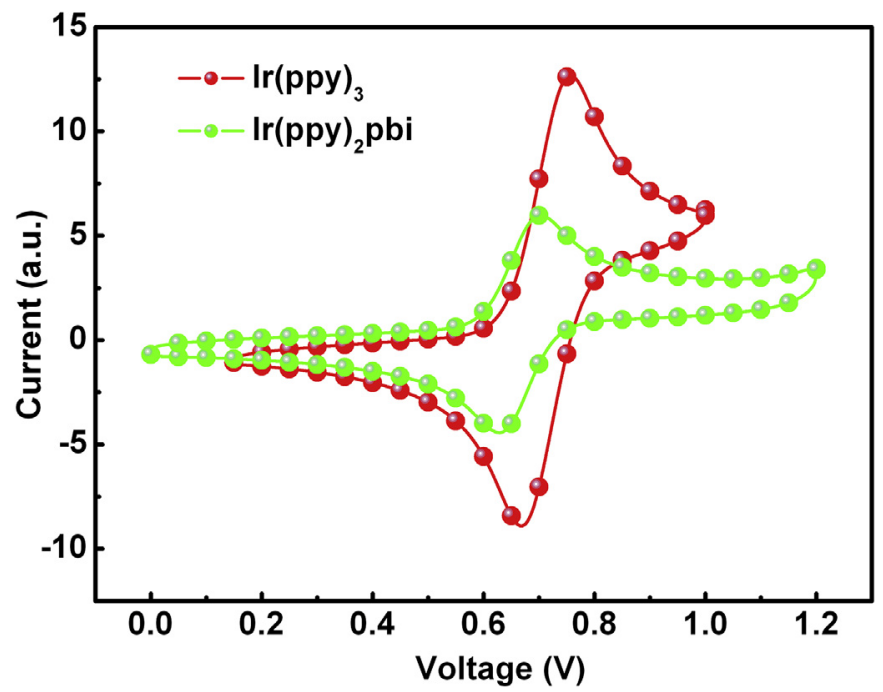

Fig. 3. Cyclic voltammetry curves of (cyclopbi) $)_{2} \mathrm{Iracac}$ and (cyclopbi) $)_{2} \mathrm{IrCF}_{3}$ in dichloromethane solution.
Table 1

Photophysics and electrochemistry characteristics of complexes $\operatorname{Ir}(\mathrm{ppy})_{3}$ and $\operatorname{Ir}(\mathrm{p}-$ py) $)_{2}$ pbi in dichloromethane solution.

\begin{tabular}{|c|c|c|c|c|c|c|c|}
\hline Complexes & Abs (nm) & $\begin{array}{l}\mathrm{PL} \\
(\mathrm{nm})\end{array}$ & $\varphi$ & $\begin{array}{l}E_{g}^{a} \\
(\mathrm{eV})\end{array}$ & $\begin{array}{l}E_{\mathrm{ox}} \\
(\mathrm{V})\end{array}$ & $\begin{array}{l}\mathrm{HOMO}^{\mathrm{b}} \\
(\mathrm{eV})\end{array}$ & $\begin{array}{l}\text { LUMO } \\
(\mathrm{eV})\end{array}$ \\
\hline $\operatorname{Ir}(\mathrm{ppy})_{3}$ & $\begin{array}{l}345.8,378.7,405.7 \\
453.2,485.4\end{array}$ & 514 & 0.40 & 2.08 & 0.64 & -4.92 & -2.84 \\
\hline $\operatorname{Ir}(\mathrm{ppy})_{2} \mathrm{pbi}$ & $\begin{array}{l}374.8,408.4,454.5 \\
488.1\end{array}$ & 517 & 0.21 & 2.07 & 0.61 & -4.89 & -2.82 \\
\hline
\end{tabular}

\subsection{Electroluminescence characteristics}

As is well known, the efficiency of phosphorescent OLEDs drops markedly as the doping concentration increased because of the strong concentration quenching, in addition, incomplete Dexter energy transfer will exit as the doping concentration decreased which cause strong NPB or CBP emission [18]. The electroluminescence characteristics of $\operatorname{Ir}(\mathrm{ppy})_{3}$ and $\operatorname{Ir}(\mathrm{ppy})_{2} \mathrm{pbi}$ are shown in Fig. 4. The optimized doping concentration of $\operatorname{Ir}(\mathrm{ppy})_{3}$ was $6 \mathrm{wt} \%$, and the device showed the maximum current efficiency $\left(\eta_{c}\right)$ of $30.9 \mathrm{~cd} / \mathrm{A}$ and maximum brightness of $50,340 \mathrm{~cd} / \mathrm{m}^{2}$, however, because of the strong TTA, efficiency dropped badly to $23.4 \mathrm{~cd} / \mathrm{A}$ at $215.3 \mathrm{~mA} / \mathrm{cm}^{2}$ with an efficiency roll-off of $24.3 \%$. Same phenomenon was obtained for $\operatorname{Ir}(\mathrm{ppy})_{2} \mathrm{pbi}$, at doping concentration $6 \mathrm{wt} \%$, the maximum $\eta_{c}$ was only about $19.5 \mathrm{~cd} / \mathrm{A}$, much lower than that of $\operatorname{Ir}(\mathrm{ppy})_{3}$, may be because of the lower $\varphi$ of $\operatorname{Ir}(\mathrm{ppy})_{2}$ pbi than $\operatorname{Ir}(\mathrm{ppy})_{3}$, and the efficiency roll-off was obviously as the current increased. However, when the doping concentration was increased to $10 \mathrm{wt} \%$, both the maximum $\eta_{c}$ and brightness were improved greatly to $24.1 \mathrm{~cd} / \mathrm{A}$ and $58,170 \mathrm{~cd} / \mathrm{m}^{2}$, respectively. Interestingly, the $\eta_{c}$ is higher than that of $\operatorname{Ir}(\mathrm{ppy})_{3}$ when the current density increased to $195.8 \mathrm{~mA} / \mathrm{cm}^{2}$. The reason was ascribed to the lower efficiency in the $\operatorname{Ir}(\mathrm{ppy})_{2}$ pbi device than the $\operatorname{Ir}(\mathrm{ppy})_{3}$ one caused by the low exciton density, which was identical to the lower photoluminescence quantum yield of $\operatorname{Ir}(\mathrm{ppy})_{2}$ pbi than $\operatorname{Ir}(\mathrm{ppy})_{3}$. In order to further investigate the TTA in this hetero-cyclometalated complex, the doping concentration was increased to $12 \mathrm{wt} \%$, as shown in Fig. $4 \mathrm{a}$, the efficiency was extremely stable from $3.5 \mathrm{~mA} / \mathrm{cm}^{2}$ to $253.2 \mathrm{~mA} / \mathrm{cm}^{2}$, and the efficiency roll-off was only about $3.4 \%$ from the maximum $\eta_{c} 26.7 \mathrm{~cd} / \mathrm{A}$ to $25.8 \mathrm{~cd} / \mathrm{A}$ at $253.2 \mathrm{~mA} / \mathrm{cm}^{2}$. At $103.1 \mathrm{~mA} / \mathrm{cm}^{2}$ and above, this device was more efficient than that of $\operatorname{Ir}(\mathrm{ppy})_{3}$ and the brightness was as high as $27,000 \mathrm{~cd} / \mathrm{m}^{2}$. We infer that the suppressed TTA was ascribed to more complicated excited states and the unsymmetrical ligand in $\operatorname{Ir}(\mathrm{ppy})_{2}$ pbi which lead to low exciton density unlike $\operatorname{Ir}(\mathrm{ppy})_{3}$ or $\operatorname{Ir}(\mathrm{ppy})_{2}$ piq in which the phosphorescence radiatively decayed only from the triplet exciton of Ir-ppy or Ir-piq.

\subsection{Theoretical calculations}

To obtain a qualitative picture on the electronic property of $\operatorname{Ir}(\mathrm{ppy})_{3}$ and $\operatorname{Ir}(\mathrm{ppy})_{2} \mathrm{pbi}$, theoretical calculations were carried out and the results were shown in Fig. 5. The optimized structures of $\operatorname{Ir}(\mathrm{ppy})_{3}$ and $\operatorname{Ir}(\mathrm{ppy})_{2}$ pbi were consistent with the experimental results. For complex Ir(ppy) $)_{3}$, because of the symmetrical structure (which was also proved by the ${ }^{1}$ HNMR data), a few HOMO (HOMO2, HOMO-1, HOMO) and LUMO (LUMO, LUMO + 1, LUMO + 2) were evenly distributed throughout the iridium atom and the three ppy ligands. Moreover, due to high symmetry, three HOMOs become degenerate and their energies are $-4.30 \mathrm{eV}$. For LUMOs, their energies are closed, namely $-1.96 \mathrm{eV}$ (LUMO) and $-1.88 \mathrm{eV}$ $($ LUMO +1 , LUMO +2$)$. However, for complex $\operatorname{Ir}(\mathrm{ppy})_{2} \mathrm{pbi}$, the 

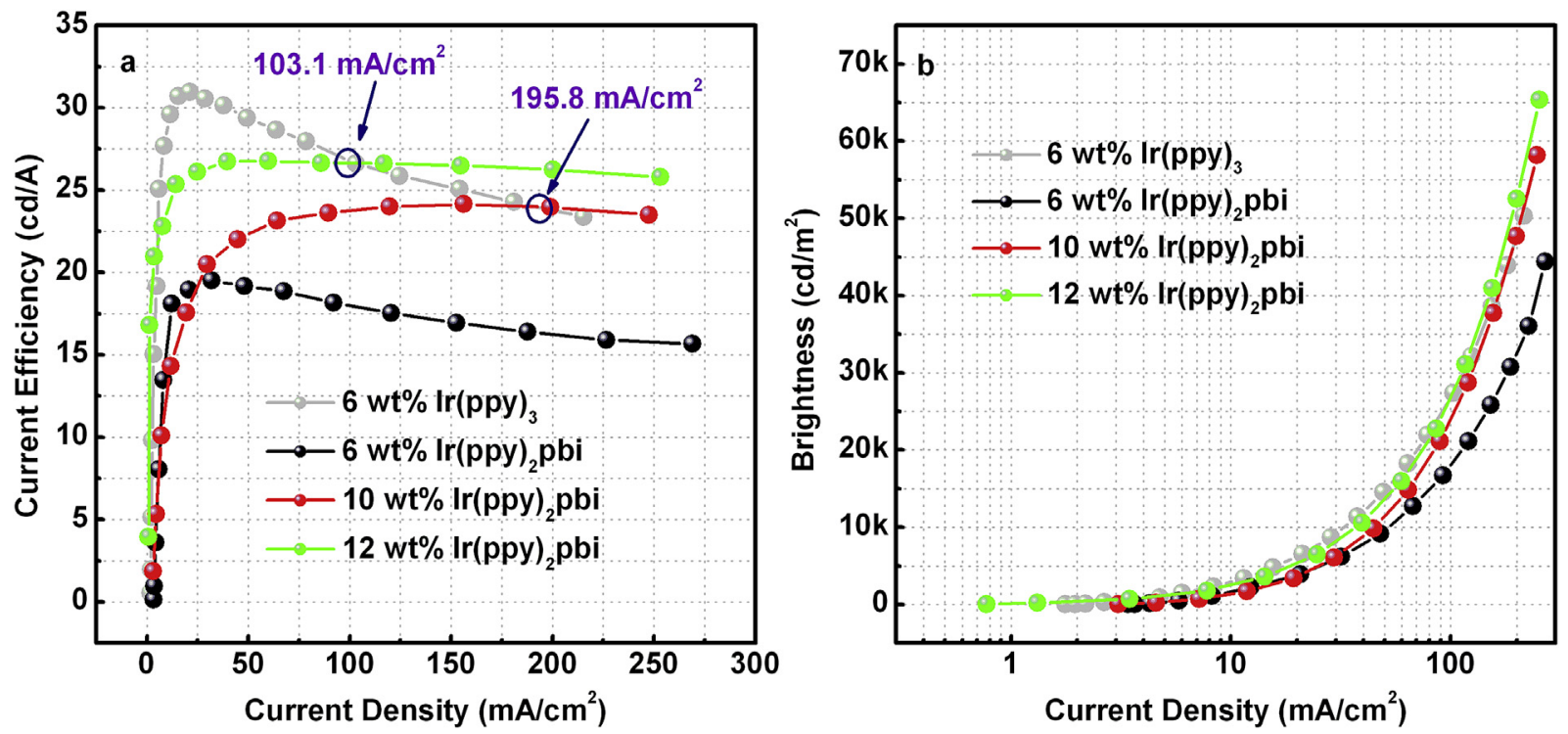

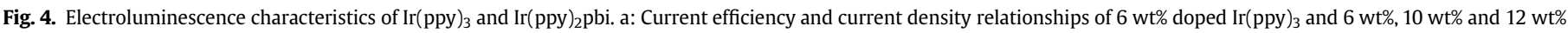
doped $\operatorname{Ir}(\mathrm{ppy})_{2} \mathrm{pbi}$; b: Brightness and current density relationships of 6 wt\% doped $\operatorname{Ir}(\mathrm{ppy})_{3}$ and 6 wt $\%, 10 \mathrm{wt} \%$ and 12 wt $\%$ doped $\operatorname{Ir}(\mathrm{ppy})_{2} \mathrm{pbi}$.

energy levels were more complicated compared to $\operatorname{Ir}(\mathrm{ppy})_{3}$, the HOMO was concentrated in the metal and the electron-rich groups of ppy and pbi with $-3.97 \mathrm{eV}$, and the HOMO- 1 and HOMO- 2 were mainly in the ppy and pbi ligand with different energy levels $-4.19 \mathrm{eV}$ and $-4.28 \mathrm{eV}$, respectively. The LUMO, LUMO +1 and LUMO +2 also show different energy levels $-1.85 \mathrm{eV},-1.77 \mathrm{eV}$ and $-1.74 \mathrm{eV}$, respectively. The calculations indicate more complicated electron transitions may exist in the complex $\operatorname{Ir}(\mathrm{ppy})_{2} \mathrm{pbi}$, because the introduction of different cyclometalated ligands destroys the high symmetry of cyclometalated complexes. As the result of the loss of electronic-state degeneracy, different types of triplet excitons may be generated when $\operatorname{Ir}(\mathrm{ppy})_{2} \mathrm{pbi}$ is excited. Thus in the visible absorption range the distance between the same kind of exciton becomes large, which results in

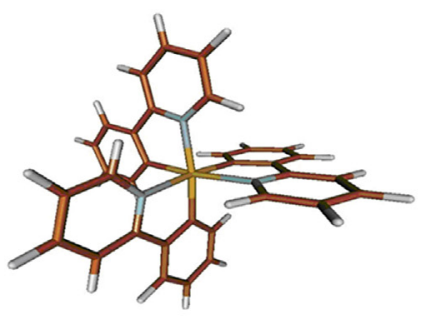

$\operatorname{Ir}(\mathrm{ppy})_{3}$

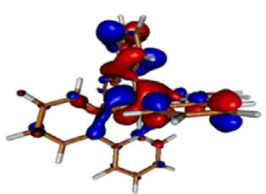

HOMO-2

$(-0.158)$

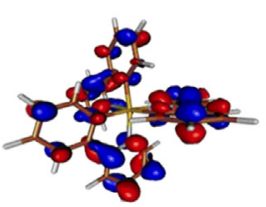

LUMO

$(-0.072)$
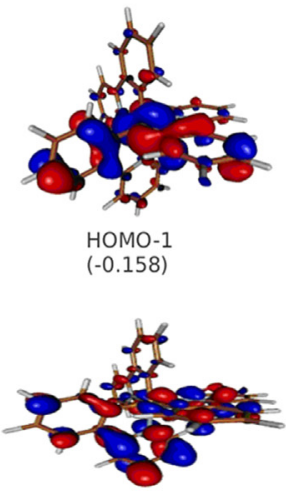

LUMO+1
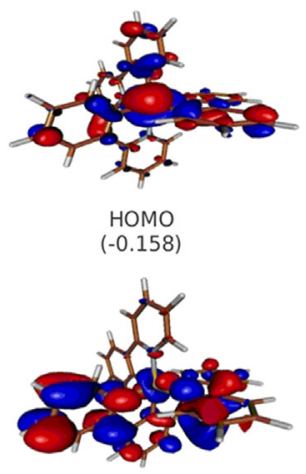

$\mathrm{LUMO}+2$

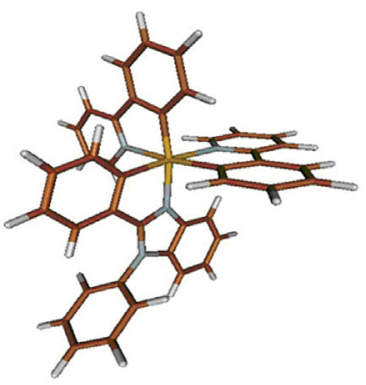

$\operatorname{Ir}(\mathrm{ppy})_{2} \mathrm{pbi}$

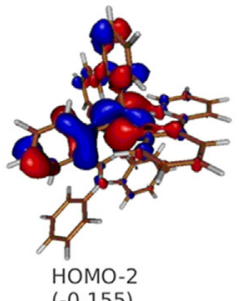

$(-0.155)$
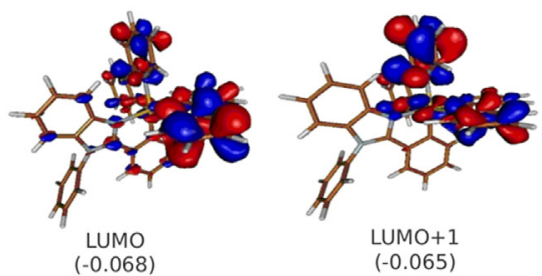

Fig. 5. Optimized structures and plots of molecular orbital of $\operatorname{Ir}(\mathrm{ppy})_{3}$ and $\operatorname{Ir}(\mathrm{ppy})_{2} \mathrm{pbi}$ with corresponding energies in Hartree unit. 
suppressed TTA. More detailed dynamic processes are still underway and the result will be published in due course.

\section{Conclusion}

In conclusion, high efficiency and efficiency-stable phosphorescent OLEDs were obtained based on the hetero-cyclometalated iridium complex $\operatorname{Ir}(\mathrm{ppy})_{2}$ pbi. The maximum $\eta_{c} 26.7 \mathrm{~cd} / \mathrm{A}$ was obtained and the $\eta_{c}$ was still maintained at $25.8 \mathrm{~cd} / \mathrm{A}$ when the current density was above $253.2 \mathrm{~mA} / \mathrm{cm}^{2}$, only $3.4 \%$ efficiency roll-off. Both the triplet state of Ir-ppy and Ir-pbi contributed to the phosphorescence because of the complicated energy level and unsymmetical ligand in $\operatorname{Ir}(\mathrm{ppy})_{2} \mathrm{pbi}$, which was qualitatively proved by theoretical calculations. This result could be very interesting and useful when designing efficiency phosphorescent materials with lower efficiency decay.

\section{Acknowledgments}

The work was supported by National Natural Science Foundation of China (21103213, 21274161, 51173199, 91233106 and 91123034), Outstanding Young Scientists Research Award Fund of Shandong Province (BS2010NJ021), Shandong Provincial Natural Science Foundation (ZR2011BZ007), Strategic Priority Research Program of the Chinese Academy of Sciences (XDA09020201), and National Science and Technology Ministry (2012BAF13B05-402).

\section{References}

[1] Ho PKH, Kim JS, Burroughes JH, Becker H, Li SFY, Brown TM, et al. Molecularscale interface engineering for polymer light- emitting diodes. Nature 2000;404:481-4.

[2] Gu G, Parthasarathy G, Forrest SR. A metal-free, full-color stacked organic light-emitting device. Appl Phys Lett 1999;74:305-7.

[3] Wu CC, Chen CW, Cho TY. Three-color reconfigurable organic light-emitting devices. Appl Phys Lett 2003:83:611-3.

[4] Baldo MA, O'Brien DF, You Y, Shoustikov A, Sibley S, Thompson ME, et al. Highly efficient phosphorescent emission from organic electroluminescent devices. Nature 1998;395:151-4.

[5] Adachi C, Baldo MA, Thompson ME, Forrest SR. Nearly 100\% internal phosphorescence efficiency in an organic light-emitting device. J Appl Phys 2001;90:5048-51.

[6] Ikai M, Tokito S, Sakamoto Y, Suzuki T, Taga Y. Highly efficient phosphorescence from organic light-emitting devices with an exciton-block layer. Appl Phys Lett 2001;79:156.

[7] Lamansky S, Djurovich P, Murphy D, Razzaq FA, Lee HE, Adachi C, et al. Highly phosphorescent bis-cyclometalated iridium complexes: synthesis, photophysical characterization, and use in organic light emitting diodes. J Am Chem Soc 2001;123:4304-12.

[8] Wang Q, Chen YH, Chen JS, Ma DG. White top-emitting organic light-emitting diodes employing tandem structure. Appl Phys Lett 2012;101:133302.

[9] Baldo MA, Lamansky S, Burrows PE, Thompson ME, Forrest SR. Very highefficiency green organic light-emitting devices based on electrophosphorescence. Appl Phys Lett 1999;75:4.

[10] Baldo MA, Adachi C, Forrest SR. Transient analysis of organic electrophosphorescence. II. Transient analysis of triplet-triplet annihilation. Phys Rev B 2000;62:10967-77.

[11] Fukagawa H, Shimizu T, Ohbe N, Tokito S, Tokumaru K, Fujikake H. Anthracene derivatives as efficient emitting hosts for blue organic light-emitting diodes utilizing triplet-triplet annihilation. Org Electron 2012;13:1197-203.
[12] Wu C, Tao SL, Chen MM, Wong FL, Yang QD, Mo HW. Highly efficient blue and white phosphorescent OLEDs based on an iridium complex. Dyes Pigments 2013;96:237-41.

[13] Yang W, Chen YS, Jiang W, Ban XX, Huang B, Dai YQ, et al. A carbazole-based dendritic host material for efficient solution-processed blue phosphorescent OLEDs. Dyes Pigments 2013;97:286-90.

[14] Kajii H, Takahota N, Wang YD, Ohmori Y. Current-density dependence of transient properties in green phosphorescent organic light-emitting diodes. Jpn J Appl Phys 2011;50. 04DK05.

[15] Yang XH, Jabbour GE. Efficient light emitting devices based on phosphorescent partially doped emissive layers. J Mater Chem C 2013;1:4663-6.

[16] Reineke S, Walzer K, Leo K. Triplet-exciton quenching in organic phosphorescent light-emitting diodes with Ir-based emitters. Phys Rev B 2007;75: 125328.

[17] Wu CH, Shih PI, Shu CF, Chi Y. Highly efficient red organic light-emitting devices based on a fluorene-triphenylamine host doped with an Os(II) phosphor. Appl Phys Lett 2008;92:233303.

[18] Han LL, Yang DF, Li WL, Chu B, Chen YR, Su ZS, et al. The reduced triplet-triplet annihilation of electrophosphorescent device doped by an iridium complex with active hydrogen. Appl Phys Lett 2008;93:153303.

[19] Lee JY. Intramolecular energy transfer in heteroleptic red phosphorescent dopants. Appl Phys Lett 2006;89:223517.

[20] Li YF, Cao Y, Gao J, Wang DL, Yu G, Heeger AJ. Electrochemical properties of luminescent polymers and polymer light-emitting electrochemical cells. Synth Met 1999;99:243-8.

[21] Becke AD. Density-functional thermochemistry. III. The role of exact exchange. J Chem Phys 1993:98:5648.

[22] Stephens PJ, Devlin FJ, Chabalowski CF, Frisch MJJ. Ab initio calculation of vibrational absorption and circular dichroism spectra using density functional force fields. J Phys Chem 1994;98:11623-7.

[23] Weigend F, Ahlrichs R. Balanced basis sets of split valence, triple zeta valence and quadruple zeta valence quality for $\mathrm{H}$ to Rn: design and assessment of accuracy. Phys Chem Chem Phys 2005;7:3297-305.

[24] Neese F. ORCA - an ab initio, density functional and semi empirical program package V 2.9 development. D-45470 Muelheim/Ruhr, Germany: Max Planck Institute for Bioinorganic Chemistry; 2012.

[25] Huang WS, Lin JT, Chien CH, Tao YT, Sun SS, Wen YS. Highly phosphorescent bis-cyclometalated iridium complexes containing benzoimidazole-based ligands. Chem Mater 2004;16:2480-8.

[26] You Y, Park SY. Inter-Ligand energy transfer and related emission change in the cyclometalated heteroleptic iridium complex: facile and efficient color tuning over the whole visible range by the ancillary ligand structure. J Am Chem Soc 2005; $127: 12438-9$.

[27] Kwon TH, Cho HS, Kim MK, Kim JW, Kim JJ, Lee KH, et al. Color tuning of cyclometalated iridium complexes through modification of phenylpyrazole derivatives and ancillary ligand based on ab initio calculations. Organometallics 2005;24:1578-85.

[28] Han LL, Yang DF, Li WL, Chu B, Chen YR, Su ZS, et al. Intramolecular energy transfer between the triplet of ancillary ligand and the metal to ligand charge transfer state existed in heterocyclometalated iridium (III) complexes. Appl Phys Lett 2009;94:163303.

[29] Ding JQ Gao J, Cheng YX, Xie ZY, Wang LX, Ma DG, et al. Highly efficient green-emitting phosphorescent iridium dendrimers based on carbazole dendrons. Adv Funct Mater 2006;16:575-81.

[30] Baldo MA, Adachi C, Forrest SR. Transient analysis of organic electrophosphorescence: I. Transient analysis of triplet energy transfer. Phys Rev B 2000;62:10958-66.

[31] Deng LJ, Zhang T, Wang RJ, Li JY. Diphenylphosphorylpyridine-functionalized iridium complexes for high-efficiency monochromic and white organic lightemitting diodes. J Mater Chem 2012;22:15910-8.

[32] Su HC, Fang FC, Hwu TY, Hsieh HH, Chen HF, Lee GH, et al. Highly efficient orange and green solid-state light-emitting electrochemical cells based on cationic Ir III complexes with enhanced steric hindrance. Adv Funct Mater 2007; 17:1019-27.

[33] Han LL, Zhang DY, Zhou YH, Yang Y, Woo HY, Bai FL, et al. Greenish yellow organic light emitting devices based on novel iridium complexes containing 2-cyclohexenyl-1-phenyl-1H-benzo[d]imidazole. Dyes Pigments 2013;99: $1010-5$. 